\title{
OM MINIATUREMALEREN CHR. HORNEMAN OG FAMILIEN GERSON
}

\author{
AF
}

Torben Holck Colding

\begin{abstract}
T Komponisten C.F.E. Hornemans Papirer i Det kongelige Bibliotek'
ligger sex smaa, lidt uregelmzessigt tilskaarne Plader af grunderet Karton med Tegninger i Metalstift. De er udført af Komponistens Farfar, Christian Horneman (1765-1844) i den saakaldte „à la CarvelleTeknik ", som han, saavidt man ved, havde lært under sit Ophold i Berlin i $1796 \mathrm{og}$ ofte praktiseret ogsaa efter sin Hjemkomst til Danmark $1803 .^{2}$ Fire af disse er Portrætter, de to andre er løsere Rids, som ikke skal gøres til Genstand for sæerlig Omtale her. Af disse fire Portrætter er det tidligste (1) udført omkring Aar 1800. Det er omhyggeligt gennemtegnet og i Ansigtspartiet belagt med ganske svag Farve. Foroven bærer det en Indskrift i Kunstnerens Haand, hvoraf kun Ordene „Busch ...... i Rom“ kan tydes med nogenlunde Sikkerhed. Det må dermed formodes, at Portrættet forestiller Johann Jürgen Busch (17581820 ), der var uddannet ved Kunstakademiet i København i Begyndelsen af 1780'erne, samtidig med Horneman, og som fra $1783 \mathrm{og}$ Resten af sit Liv levede som Billedhugger i Rom. Horneman besøgte Rom i 1790, men havde paa det Tidspunkt endnu ikke lært at tegne „à la Carvelle“. Dersom Portræettet forestiller Busch, nødes man til at tro, at Horneman endnu en Gang har været i Rom og da antagelig omkring 1801. Der haves ikke en detailleret Viden om hans Ferden under hans lange Udenlandsrejse 1788-1803, kun visse Holdepunkter og det vides, at han rejste flere Gange frem og tilbage mellem Landene og de store Byer i Centraleuropa. Den Mulighed staar ogsaa aaben, at Busch har

${ }^{1} \mathrm{Ny}$ kgl. Saml. 2081 fol.

2 Torben Holck Colding: „À la Carvelle“ i Meddelelser fra Thorvaldsens Museum 1989 , S. $54 \mathrm{ff}$.
\end{abstract}


besøgt Horneman i Wien eller i Berlin i Aarene omkring Aarhundredeskiftet.

Den anden Tegning (2) er udført i København i Slutningen af Aaret 1803, efter at Kunstneren havde faaet til Opgave som Receptionsstykke til Kunstakademiet at male en Miniature af Prins Christian Frederik (Christian VIII). Tegningen er et første løst Udkast til denne Miniature. Man ser, hvordan han har overvejet forskellige Muligheder for Anbringelsen af Figuren. Prinsen omtaler Miniaturens Tilblivelse i et Dagbogsnotat af 4 . Januar $1804 .^{3}$ To Maaneder senere blev den enstemmigt antaget af Akademiets Forsamling. ${ }^{4}$

Den tredie Tegning (3) er en Skitse til en cirkelrund Miniature, forestillende to unge Piger. Kunstneren har selv skrevet på Tegningen „Schimmelmanns Børn 1804." Herefter maa det dreje sig om Friedrich Joseph Schimmelmanns Døtre, Caroline Frederikke (1778-1858), der 1796 var blevet gift med Grev F.V. le Merchier de Criminil og Charlotte (1790-1852), der 1807 blev gift med Grev Ditlev Christian Reventlow til Brahetrolleborg.

Den fjerde Tegning forestiller en siddende Dreng. (4) Den bærer Indskriften „Til Nicolai Gersons Portrait i Pastel.“

Chajim Königsberg (1765-1839) etablerede sig i Slutningen af det 18. Aarhundrede i København under Navnet Heyman Gerson som Stadsmægler og fik betydelig økonomisk Succes. Han giftede sig første Gang med et Medlem af den ansete Slægt Melchior, Esperance, der døde kun 26 Aar gammel i 1797, anden Gang med den rige Vexelmægler Joseph Nathan Davids Søster, Emilie, Datter af Købmand i Altona Nathan David..$^{5}$ I hvert af disse Egteskaber fødtes to Børn, George, Rosa, Nicolay og Augusta. Disse fire Søskende synes alle at have haft et engageret Forhold til Musik. De tre yngste var Medlemmer af Musikforeningen fra dens Stiftelse ${ }^{6} 1836$. De to Sønner blev begge Forretningsmand ligesom deres Fader.

Den ældste George (f. 1790) kom 1806 i Handelslære i Hamburg. Ved Hjemkomsten herfra 1812 blev han ansat i Hambros Bank og 1816

\footnotetext{
3 Kong Christian VIIIs Dagboger og Optegnelser, 1, udg. ved Axel Linvald, 1943, S. 220, 571 .

4 E.F.S. Lund: Danske malede Portrater, V , 1906, S. 10.

"Harald Jørgensen: C. N. David, I, 1950, S. 7 ff. Jeg takker Undervisningsinspektør cand. jur. Hans Metzon for vigtige personalhistoriske Oplysninger om Slagten Gerson.

${ }^{6}$ Angul Hammerich: Musikforeningens Historie, 1886, S. 232.
} 


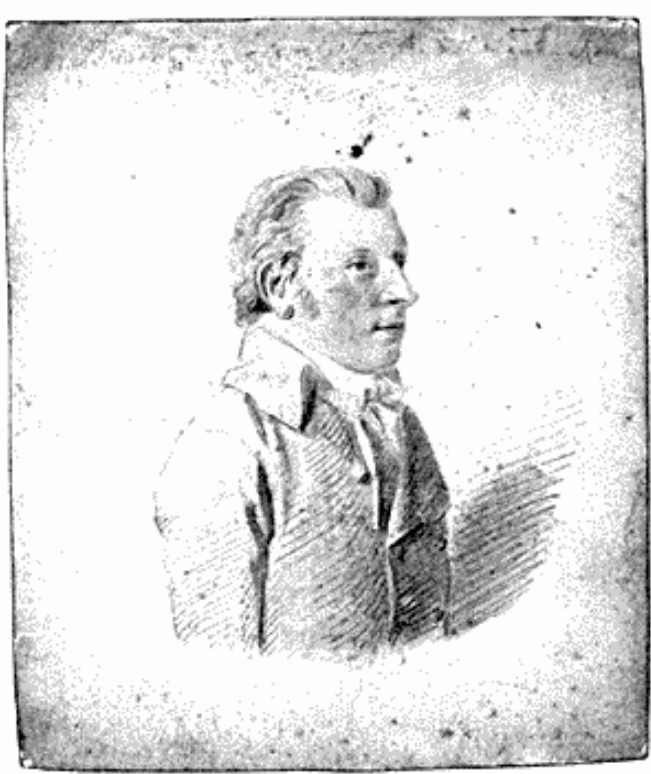

2

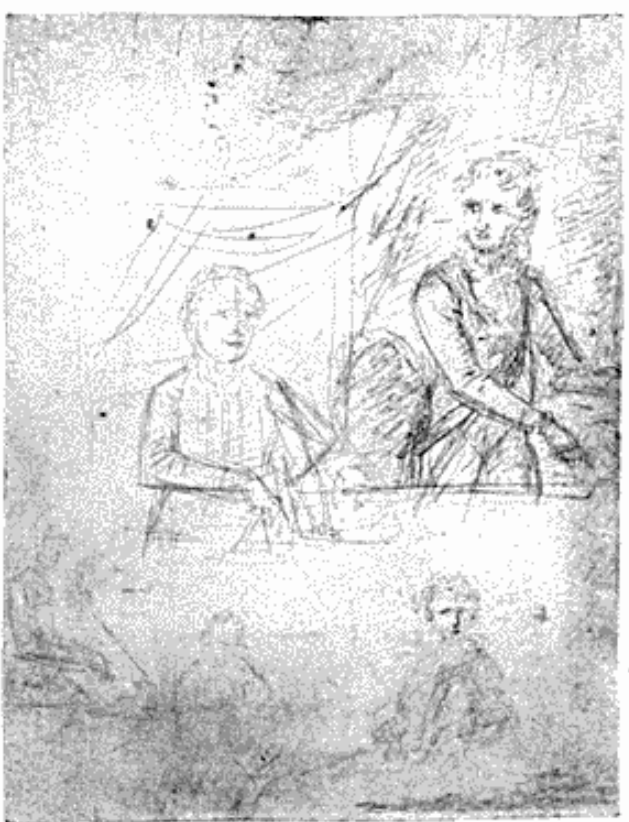

4
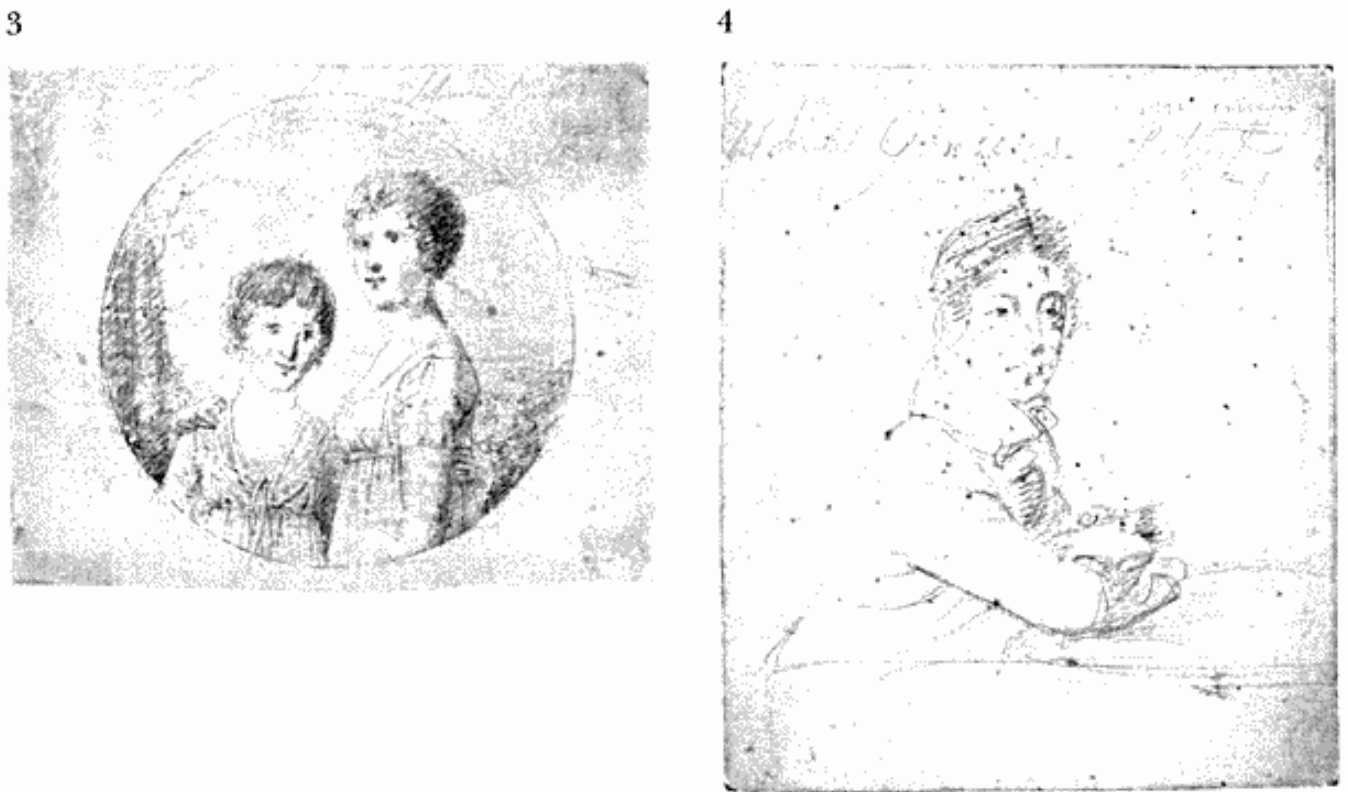

1-4. C. Horneman Skitser af 1. J. J. Busch, 2. Prins Christian Frederik 1803, 3. Schimmelmanns Døtre 1804, 4. Nicolay Gerson. Alle tilhører Det kgl. Bibliotek. 
Associé; 1821 blev han og Joseph Hambro benaadet med den sjeldent uddelte Titel Hofraad som Tak for Tjenester, de havde ydet den danske Regering ved Optagelse af et Statslaan i England paa $£ 3.000 .000{ }^{7}$

Han havde allerede som Barn modtaget grundig Musikundervisning og i 1804 skrevet sin første Komposition.

1807 stiftede han i Hamburg Bekendtskab med en af Europas førende Violinvirtuoser paa den Tid, Andreas Romberg, der gav ham Undervisning baade i Violinspil og i Komposition. Violinen var og blev hans Yndlingsinstrument, som han haandterede med Mesterskab. Hvert af hans Buestrøg - sagde man - var fuldt af Sang. ${ }^{8}$

1823 skrev han en Fortegnelse over sine Kompositioner, der paa det Tidspunkt omfattede 200 Numre. Den findes i Det kongelige Bibliotek og er indbundet i et sjældent smukt Helbind af Saffian. ${ }^{9}$

Hans første trykte Arbejde er fra 1815, Indtogsmarch ved Frederik VI's Hjemkomst fra Wienerkongressen. Men Aaret før havde „Det harmoniske Selskab" spillet en Koncertouverture af ham, samtidig med at man havde haft en Symfoni af Beethoven (den 7.?) paa Programmet ${ }^{10}$ Hans Kompositioner omfattede Kammermusik, Orkesterværker, et Paternoster for Mandskor og Sange med Text, bl.a. af Jens Baggesen. Efter hans Død udgav Koncertforeningen „Sex Sange“ 1842." Hans Symfoni i Es Dur, paabegyndt 1817, er udgivet efter Originalmanuskriptet i $1983 .^{12}$

Hans Dage var stærkt optaget af hans praktiske Virksomhed som Finansmand, men i Frokostpauserne foretog han daglige Rideture, og her udtænkte han til Hest sine Kompositioner, som han om Aftenen

7 Bo Bramsen \& Kathleen Wain: The Hambros, London 1979, S. 174.

8 Tidsskrift for Musik (Red. Im. Ree) 2. Aargang 1858 No. 3, en "Nekrolog“ over George Gerson, der angives „nedskrevet efter Optegnelse fra en agtet Haand“. Kilden er sandsynligvis Bankmanden Wilhelm Smidt, der blev ansat i Hambros Firma $1820 \mathrm{og}$ altsaa i fem Aar var Medarbejder med Gerson. Han ejede paa den Tid „Nekrologen“ udkom Gersons Partiturer og Varkfortegnelse (jvf. Note 9) og var Medlem af Musikforeningen fra dens Stiftelse.

${ }^{9}$ K.B. M.U. 71050963 C II 6 b Fortegnelsen barer Titlen „Verzeichniß über Zwei Hundert meiner Compositionen“. Et Forord, dateret Nov. 1823 indeholder en Del selvbiografiske Oplysninger

${ }^{10}$ V. Ravn: Koncerter og Musikalske Selskaber i aldre Tid, 1886, S. 143-44.

${ }^{11}$ Dan Fog: Dansk Musikfortegnelse, I, 1979, S. 37.

${ }^{12}$ Barry S. Brook: The Symphony 1720-1840, Ser F VI The Symphony in Denmark, New York 1983. Jeg takker mag. art. Niels Bo Foltmann for denne Henvisning. 
5. C. Horneman: Georges Gerson. Sølvstiftegning. Tilhører Gustav Helsted.

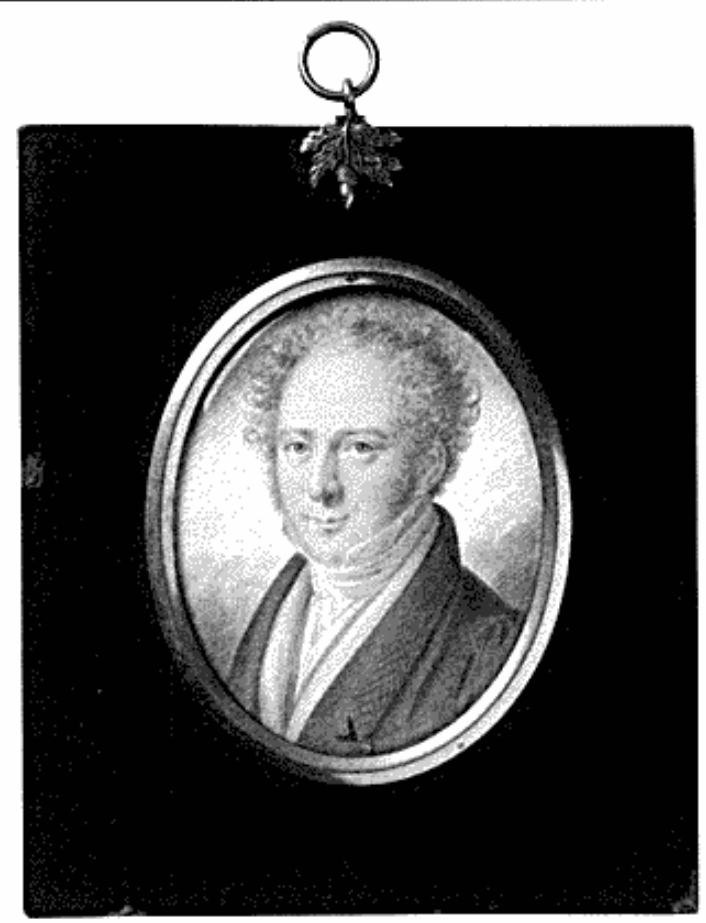

og Natten satte på Papiret. ${ }^{13}$ Hans Forretninger førte ham paa lange Rejser til Göteborg 1813, Berlin og Stettin 1817, London 1821, Paris 1822, München 1823. Overalt fandt han Udvej for at komponere, om ikke andre Steder, saa i Diligencen naar den skumplede af Sted paa de lange Veje. Paa en saadan Tur paa Vejen mellem Hamburg og København i 1812 blev en Violinkvartet komponeret.."

Gerson havde baade forretningsmæssig og venskabelig Forbindelse med Jens Baggesen. I et langt Brev til ham, dateret 21. Nov. $1820{ }^{15}$ skriver han først om Forretningsanliggender, derefter om Musiklivet i København og de Bestræbelser, der paa den Tid blev gjort for at faa afholdt lødige Koncerter, bl.a. ved Oprettelse af Selskabet til Musikkens Udbredelse. Gerson paatager sig ikke Æren, men i Virkeligheden var det ham, der var Ildsjælen og Igangsætteren af disse Koncerter, der afholdtes i Hofteatret.

\footnotetext{
${ }^{13}$ Tidsskrift for Musik I.c.

${ }^{14}$ Det i Note 9 omtalte Forord.

${ }^{15}$ KB. Ny kgl. Saml. 2252, $4^{\circ}$ I A 2.
} 


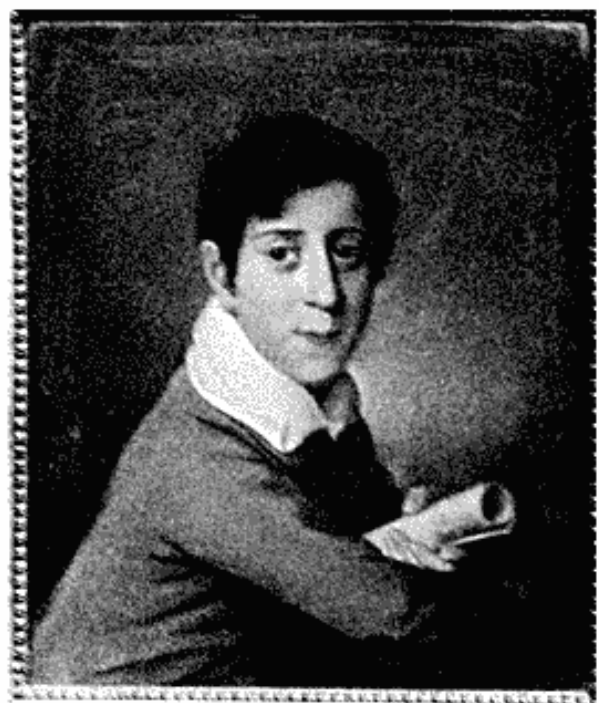

6. C. Horneman: Nicolay Gerson.

Pastel. Tilhører Ruth Berner, Clausholm.

Hans Svoger, Benny David fortæller i sine Erindringer, ${ }^{16}$ at da den verdensberømte Cellist og Komponist Bernhard Romberg, en Fætter til Gersons Lærer i Hamburg, efter hans Død saa et Portræt af ham, sagde han ,Als Kaufmann war er ein Finanzminister, als Dilettant ein vollendeter Künstler." Gerson var en alsidig Begavelse, han talte og skrev engelsk, tysk og fransk, var livlig, elegant, høj og smuk. ${ }^{17}$ Han giftede sig 1824 med sin Stifmoders Broderdatter, Joseph Nathan Davids næstyngste Barn, Adelaide, men døde fire Maaneder efter Brylluppet $1825 \mathrm{og}$ blev begravet paa Mosaisk Kirkegaard i Møllegade, hvor en statelig Gravstele endnu markerer hans Hvilested. ${ }^{18}$ Hans Arvinger skænkede efter hans Død i hans Navn ni Legater paa tilsammen over 20.000 Rdr. De største til Københavns Universitet til to mosaiske Studerende (5000 Rdr.), til fire Senge på Vartov til Kristne Trængende (4.400 Rdr.) og til Frederiks Hospital (5000 Rdr.) til Pleje af en fattig og syg. ${ }^{19}$

16 ,Af Benny Davids Erindringer“ i Vor Fortid, I, 1917, S. 474.

${ }^{17}$ N.C.L. Abrahams: Meddelelser af mit Liv, 1876, S. $76 \mathrm{ff}$.

${ }^{18}$ Elias Levin: Den gamle jodiske Begravelsesplads i Mollegade, I, 1994, S. 121.

${ }^{19}$ H. R. Hiort-Lorenzen og Ellen Rosendahl: Repertorium over Legater og milde Stiftelser i Danmark, 1903; V. Bitsch i Historiske Meddelelser om Kobenhazn 3. Rk. I, 1935. s 85; Fr. Gredsted: Det Kgl. Frederiks Hospital, 1907. S. 110. Paa Rigshospitalet er ophængt en Mindetavle med følgende Indskrift: „For afgangne Hofraad George Gerson i Aaret 1827 skiænkede Legat til det kongelige Frederiks Hospital af $5000 \mathrm{Rbd}$. Sølv, Nyder een fattig syg Frikuur og Pleye." 
George Gersons yngre Halvbroder Nicolay (f. 1802) dyrkede Klaveret med Lidenskab og Dygtighed, og var fra Drengeaarene Elev af Friedrich Kuhlau. 13 Aar gammel, den 13. December 1815, spillede han ved en Koncert i Det harmoniske Selskab Mozarts Koncert for to Klaverer sammen med sin Lærer. ${ }^{20}$

H.C. Andersen omtaler ham et Par Gange i sine Dagbøger som „lille Gerson ". ${ }^{21}$

Og lille var han af Kropsbygning i Modsatning til Broderen. Han var et Følelsesmenneske, ikke som denne en intellektuel Type. Han ejede ikke den Harmoni i sit Væsen, den Sikkerhed i sin Optræden, som han."2

For at styrke hans Udvikling besluttede hans velhavende Fader at sende ham ud paa en langere Uddannelsesrejse, og da han var upraktisk og naiv, blev det bestemt, at han skulde rejse med en Vejleder. Hertil udvalgte Faderen den musikalske og sprogbegavede N.C.L. Abrahams. Rejsen der varede fra 1825 til 1828, gik Europa rundt med lange Ophold i Berlin, Wien, Rom og Paris. ${ }^{23}$ Han stiftede på denne Tur Bekendtskab med en stor Del af Europas Musikere og Kunstnere. Gerson spillede ofte, hvor han kom frem, Thorvaldsen var taknemmelig for hver Gang, han spillede for ham. Rejsen er detailleret beskrevet i Abrahams' Erindringer. En Situation foregaar i et Nonnekloster i Prag. Abrahams skildrer „en højst malerisk Scene: I Midten den lille Gerson ved Flyglet, og rundt om ham en Mængde henrykte og begejstrede Nonner, af hvilke især Søster Angela var meget begejstret. Hun hviskede Gerson af og til ind i Øret, saa at vi Andre siden spurgte, om hun havde kysset ham. ${ }^{\text {"4 }}$

Efter Hjemkomsten optraadte han nogle Gange som Solist ved Koncerter i København. ${ }^{25}$ Han var med i den lille Kreds, der under Opførelsen af Festen paa Kenilworth i Det kongelige Teater den 5. Marts 1836 tog Initiativ til Stiftelsen af Koncertforeningen, og han spillede ved nogle af dens første Koncerter. ${ }^{26}$

${ }^{20}$ Gorm Busk: Friedrich Kuhlau, 1986, S. 36.

${ }^{21}$ H.C. Andersens Dagbøger 1825-75, red. af H. Topsøe-Jensen, II, 1973, S. 307, VI, 1972, S. 220.

${ }^{22}$ N .C. L. Abrahams l.c. S. $188 \mathrm{ff}$.

${ }^{23}$ Sst. S. 191-451.

${ }^{24}$ Sst. S. 218

${ }^{25}$ Angul Hammerich l.c. S. 15,52,105.

${ }^{26}$ Sst. S. 1 ff. 
Hans Yndlingskomponister var - foruden Mozart - Etienne Nicolas Méhul, Luigi Cherubini og François Adrien Boieldieu. Hans Broder foræerede ham til hans 15 Aars Fødselsdag en Ecossaise med indlagt Romance af Cherubini, som han havde komponeret i Dagens Anledning. ${ }^{27}$ Han var en god Bekendt af Weyse, som tilegnede ham sine "Quatre Études pour le Pianoforte" $1837 . .^{28}$

Han forblev ugift og boede hos sin Moder i Kronprinsessegade, saalange hun levede. Som sin Broder var han Forretningsmand; kort efter sin Tilbagekomst efter den lange Rejse var han blevet ansat i sin Svogers Firma, H.J. Goldschmidt \& Co. og drev Firmaet videre efter dennes tidlige Død sammen med Forretningens Prokurist, Levin Weil. ${ }^{29}$

Men han hengav sig nxppe til Forretningerne med samme Energi som til Musikken. Det fortælles, at en Gang, da han som sædvanlig sad ved Klaveret, fordybet $\mathrm{i}$ sit Spil, kom hans Kompagnon farende ind $\mathrm{i}$ hans Stue og raabte: „Vi gaar fallit“. Gerson svarede uden Tanke for andet end sin Musik: „Vent et Øjeblik, saa gaar jeg med“." ${ }^{30}$ Fallit gik Gerson ikke; Weyse omtaler ham som „den rige, oversparsommelige Gerson." " Han døde 1865.

Georges Helsøster, Rosa (1796-1869) blev gift 1811 med Hirsch (Henrik) Jacob Goldschmidt (1781-1829). Han var født i Danzig, men levede i København siden 1804 og ejede og drev Firmaet H. J. Goldschmidt \& Co., hvori - som omtalt - først hans Prokurist, Levin Weil, senere ogsaa Svogeren, Nicolay Gerson indtraadte. ${ }^{32}$

Som Enke boede Rosa på Kongens Nytorv under herkabelige Forhold sammen med sin Selskabsdame og sine Tjenestefolk. Hun optraadte nogle Gange som Solosanger ved Koncerter i København, ${ }^{33}$ og hendes Hjem blev Mødested for Musikelskere. ${ }^{3}$

Gerson har antagelig staaet hende nær. Til hendes Fødselsdag den 24. Januar 1820 skænkede han hende et pragtfuldt indbundet Manuskript med Titlen „Olla Potrida“ eller Ruskomsnusk,", ti Sange af egen

${ }^{27}$ Den i Note 9 omtalte Kilde No. 191.

${ }^{28}$ C.E.F. Weyse: Breve, ed. Sven Lunn og Erik Reitzel-Nielsen, II, 1964, S. 104.

${ }^{29}$ Martin Ad. Hannover: Adolph Hannovers fedrene og modrene Slagt, 1914, S. $115 \mathrm{ff}$.

${ }^{30}$ Angul Hammerich 1.c. S. 15 (Noten).

${ }^{31}$ C.E.F. Weyse 1.c. S. 29.

${ }^{32}$ Martin Ad. Hannover l.c. S. 112 ff.

${ }^{33}$ V.C. Ravn l.c. S. 145.

${ }^{34}$ N.C.L. Abrahams l.c. S. 76-77.

${ }^{35}$ KB MU 7105 061, Olla Potrida er en paa den Tid yndet spansk Bixemad (jvf. Ludvig Meyer: Fremmedordbog, 3. Udgave 1853). 


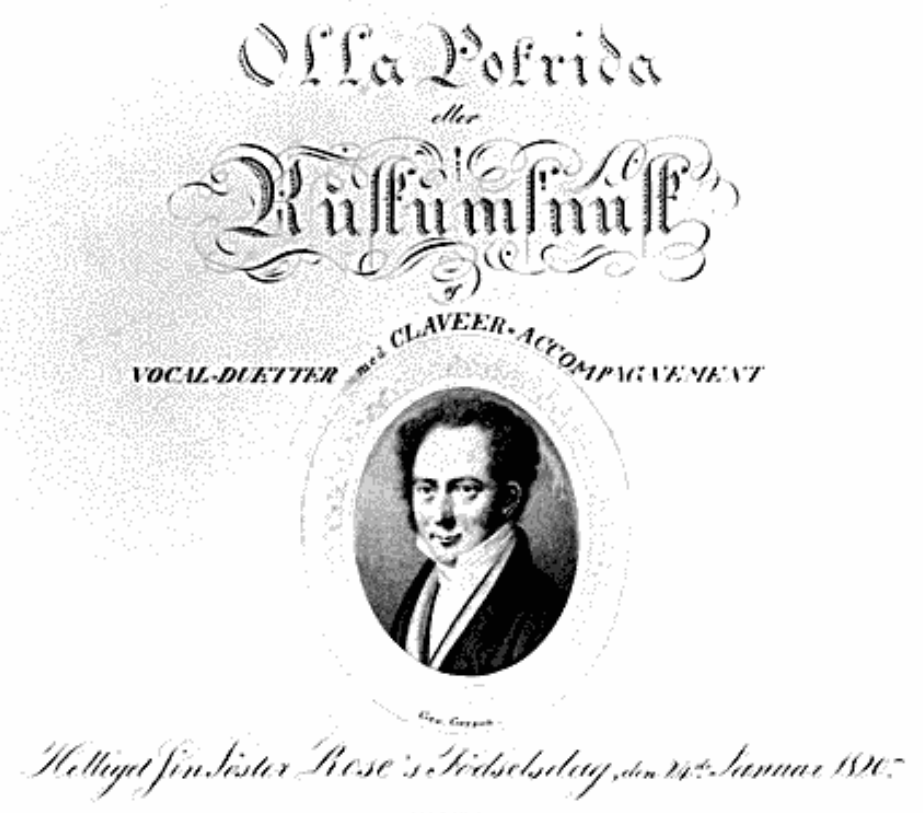

7. Titelblad (med Tegning af C. Horneman forestillende Georges Gerson) til Ms. Olla Potrida (Det kgl. Bibliotek MUFI 050961).

Komposition med Texter, bl.a. af Goethe og Jens Baggesen. (7) Efter Georges Død overtog hun hans Kompositioner i Originalhaandskrift, som hun senere forzede til Grosserer Wilhelm Smidt (1801-1884), der testamenterede dem til Musikforeningens Arkiv, hvorfra de er overgaaet til Det kongelige Bibliotek.

Nicolays Helsøster, Augusta (1815-1872) blev 1840 gift med en Jurist, Carl Ludvig Bull (1808-1879). Hun var som sin Broder Nicolay lille af Vrext, hendes Mand høj og nordisk. Man paastod, at hvis hun stillede sig op paa den Stabel Obligationer, hun havde medbragt hjemmefra, var hun lige saa høj som han. Hun var den eneste af de fire Gerson-Børn, der havde Efterslægt.

Miniature- og Pastelmaleren Christian Horneman var Musikelsker. Han fors $\varnothing m t e$ sjældent en Lejlighed til at portrættere fremragende Musikere, det være sig Komponister eller Virtuoser. Af Komponister Beethoven, Haydn, Weber, af udøvende Musikere den kejserlige Kapelmester Schirowitz i Wien, Violinisten F.C. Lemming i København 
og Sangerne Ludwig Fischer og C.F. Gerstäcker. Han var Ven med Kuhlau, som 1815 dedicerede sin Opus 15, Variationer over en nordisk Folkesang til ham, ${ }^{36} \mathrm{og}$ af hvem han samme Aar tegnede en - nu ukendt - Tegning à la Carvelle..$^{37}$

Det kan ikke overraske, at ogsaa Familien Gerson blev hans Modeller. Sandsynligvis var det i Anledning af Nicolay Gersons tidlige Debut 1815, at Horneman tegnede det foran omtalte Portræt i Det kongelige Bibliotek. (4) Tegningen blev hurtigt fulgt op af en Pastel, der erhvervedes af Familien og endnu tilhører Slægten. (6) Drengen er iført en blaa Frakke og holder i venstre Haand et sammenrullet Partitur. Pastellen er signeret og bærer en Dato, der vist nok skal læses 1816.

Dette Portræt skaffede ham hurtigt Indpas i den musikalske og velhavende Familie. En Pastel, forestillende Nicolays Svoger og senere Arbejdsgiver Hirsch Jacob Goldschmidt er dateret $1816 \mathrm{og}$ signeret Horneman (8). Modellen bærer sort Frakke og gul Vest. Det er ukendt, om der har været en Pendant, forestillende Rosa Goldschmidt, født Gerson. Hvis der har, er Portrætterne blevet skilt ved Goldschmidts Død 1829. Mandsportrættet tilfaldt da - foruden en kontant Sum - hans Søstersøn og Gudbarn, Adolph Hannover, ${ }^{38}$ i hvis Efterslægt det endnu er bevaret.

I de følgende Aar, men inden 1820, udførte Horneman adskillige Portrætter af George Gerson. En Pastel, der nu tilhører en engelsk Gren af Augustas Efterslægt, bosat i Frankrig, gengiver ham med Ansigtet en face, vendt til højre; han er iført sort Frakke, hvid Vest og Halsbind. (9) En dermed overensstemmende Miniature er i ukendt Eje. ${ }^{39}$

${ }^{36}$ Kuhlau Breve, udg. af Gorm Busk, 1990. S. 59.

${ }^{37}$ Der er registreret følgende Portratter af Kuhlau, udført af Chr. Horneman:

a) Tegning i Sølvstift, udstillet paa Salonen, Charlottenborg 1815 No 80. Ubekendt.

b) Pastel 1828, tilhørte Maleren selv, derefter hans Søn Emil og Sønnesøn C.F.E. Horneman (Jvf. E.F.S. Lund: Danske malede Portreter, VII, 1900. S. 63, med Urette som udført 1823). Derfra solgt til Generalkonsul Johan Hansen (dennes Fortegnelse No 449). Tilhører Musikhistorisk Museum.

c) Miniature, udateret, tilhører Rosenborg (Jvf. E.F.S. Lund: Danske malede Portrater, IV, 1912, S. 171).

d) Pasteller forekommer endvidere paa følgende Auktioner: Musikhandler P.W. Olsen 19/9 1858 No 9; Winkel \& Magnussen M. Grosells II Auktion 8/4 1932 No 65.

${ }^{38}$ Martin Ad. Hannover l.c. S. 116.

${ }^{39}$ Bo Bramsen \& Kathleen Wain 1.c. afb. S.158 (uden Oplysninger om Ejer). 
8. C. Horneman: H. J. Goldschmidt. Pastel. Tilhører Nina Juul.

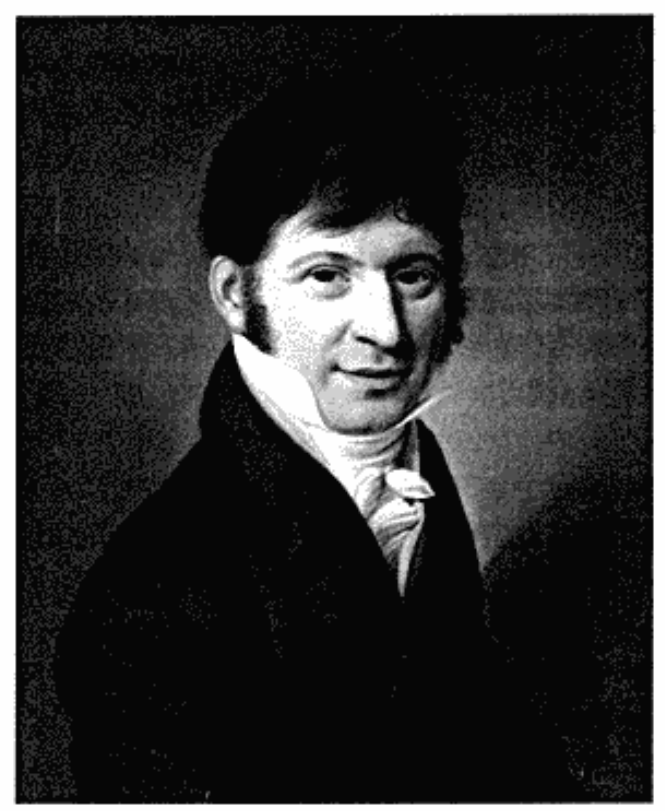

Paa de øvrige Portrætter er Ansigtet drejet til Venstre, det gælder en Tegning i Metalstift paa grunderet Karton, i den saakaldte à la Carvelle-Teknik. (5) Den er gennemarbejdet minutiøst og med stor Præcision, Farve kun antydet i Ansigtet. Saavidt ses er den hverken signeret eller dateret.

I Hambros Banks Arkiver i London findes en Miniature, der angives at forestille Carl Joachim Hambro og at være malet af en ukendt Kunstner, da Hambro som nygift opholdt sig i København i 1830 'erne. $^{40}$ Denne Datering er efter den portrætteredes Kostume mindst ti Aar for sen. Kunstneren er efter en Reproduktion at dømme temmelig sikkert Christian Horneman, Modellens Lighed med den lige omtalte Tegning à la Carvelle forestillende George Gerson er saa stor, at man faar Mistanke om, at Miniaturen snarere forestiller ham. Denne Mistanke bliver til Vished, naar man betragter et Portrat tilhørende Det kongelige Bibliotek.

Det drejer sig om Titelbladet til det ovenfor omtalte Nodemanuskript, som han forærede sin Søster Rosa paa hendes 25 Aars Fødselsdag 1820, og som bærer Titlen „Olla Potrida“. (7) Under den kalligrafisk skrevne Titel er anbragt en Tegning, udført i Blyant og Pensel med

${ }^{40}$ Bo Bramsen \& Kathleen Wain 1.c. afb. S. 219. 


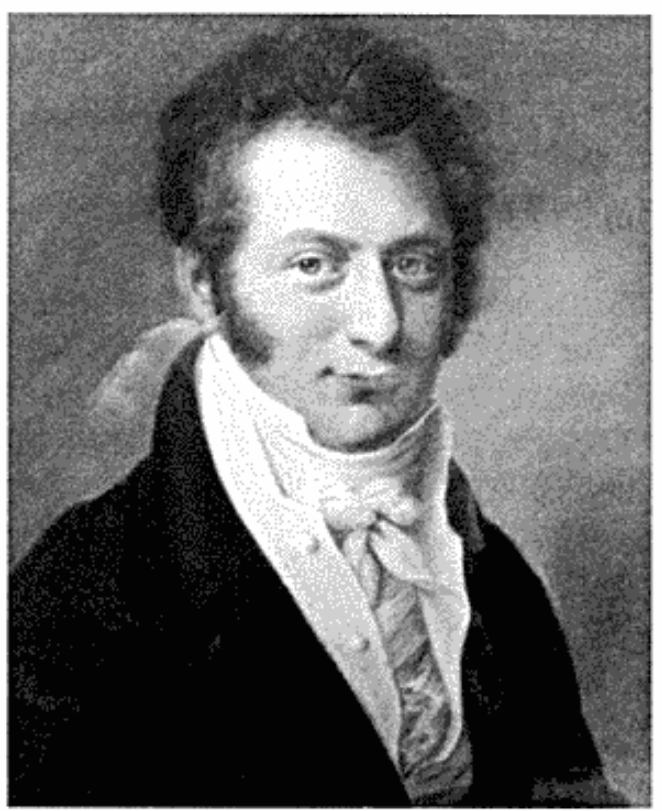

9. C. Horneman: Georges Gerson.

Pastel. Tilhører Vera Pooley, Graz.

brun og sort Tusch, direkte paa Titelbladets Papir; under Portrættet er skrevet „Geo Gerson“. Signatur findes ikke, men stregen røber umiskendeligt, at Kunsteren er Horneman. ${ }^{41}$

Flere af de omtalte Portretter af Familien Gerson blev udstillet paa den jødiske Udstilling, som blev arrangeret af Emil Hannover og afholdt i Industriforeningen i København Januar $1908 .^{42}$ Billederne tilhørte da forskellige Familiemedlemmer af Generationen efter de portrætterede. Siden er de blevet spredt mellem mange, men er stadig i Slægtens Eje.

Ogsaa af de fire musikalske Gerson'ers Fader, Heyman, fandtes paa Udstillingen et Portræt. Det tilhørte hans Dattersøn Kammerherre Otto Bull, men angaves ikke i Katalogen som malet af Horneman. ${ }^{43}$ Efterkommere efter Kammerherre Bull mener, at Portrættet blev givet en Niece. I dennes Efterkommeres Eje findes et Pastelportræt af en ubekendt midaldrende Mand, malet omkring 1815-1820 af Horne-

${ }^{41}$ Jeg takker Førstebibliotekar Ingrid Fischer Jonge for paa min Foranledning at have underkastet Tegningen en nøjere Analyse.

${ }^{42}$ Den jodiske Udstilling i Industriforeningen, 1908 No. 629-33, 635 b.

${ }^{43}$ Sst. No 628. 
10. C. Horneman: Heyman Gerson (?). Pastel. Tilhører Merete Højgaard-Jensen.

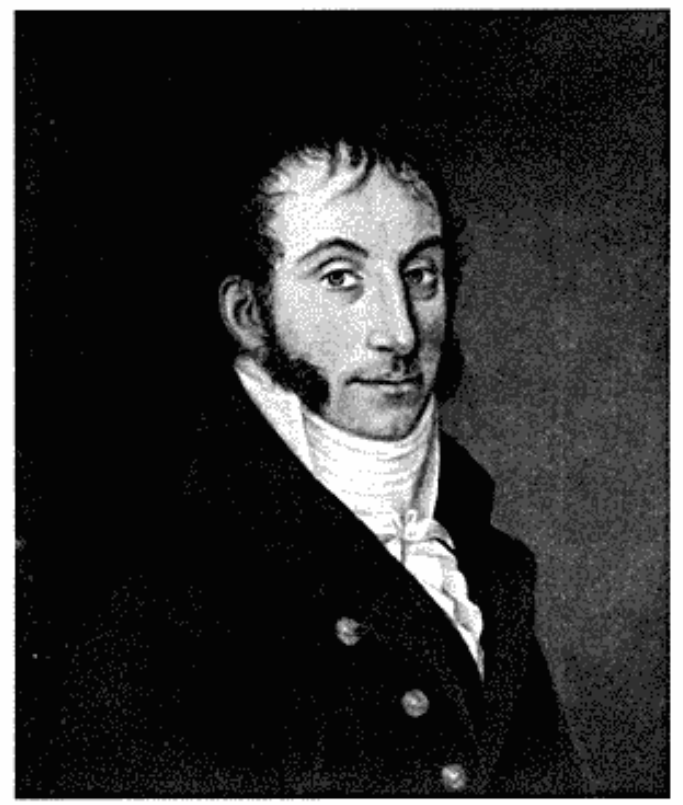

man. (10) Hans Ansigtstræk udelukker ikke, at det drejer sig om et Portræt af Stadsmægler Heyman Gerson, tværtimod synes en vis Familielighed med især Nicolays Ansigt at kunne spores.

Tilsammen udgør denne Række af ni Portrætter af den Gerson'ske Familiekreds et repræsentativt og udsøgt Udvalg af Hornemans Kunst indenfor alle de tre Arter af Portrætmaleri som var hans Speciale: à la Carvelle-Tegningen, Miniaturen og Pastellen. Og takket være ham er der overleveret Portretter af en af den Tids mest begavede Finansmænd og Musikere i Danmark, hvis Navn vilde have varet berømt i vore Dage, dersom Døden ikke havde afbrudt hans Livsbane saa tidligt.

Hambros Allé, A. N. Hansens Allé og Wilhelm Smidtsvej er opkaldt efter hans venner, de andre store Finansmænd paa den Tid. George Gerson fik ogsaa sin Vej i Nabolaget, Gersonsvej, men den er i vore Dage uretmæssigt tillagt den lidet betydelige Ophavsmand til Børnesangen „En lille Nisse rejste“"

\footnotetext{
${ }^{44}$ Evan Bogan: Kobenhavnske Gadenavne, 1993. S. 86.
} 


\section{SUMMARY}

\section{Torben Holck Colding: The Painter Chr. Horneman and the Gerson Family}

The Danish painter of pastels and miniatures, Christian Horneman, was a passionate lover of music who happily seized the opportunity to portray performers of music. He painted Beethoven in Vienna in 1802, Friedrich Kuhlau in Copenhagen in 1815 and 1828 and Carl Maria von Weber in Copenhagen in 1820. On Dec. 13, 1815, the then 13-year old Nicolay Gerson played Mozart's Concerto for two pianos (K. nr. 365) together with his teacher Kuhlau at a public concert in Copenhagen. Horneman chose this occasion to paint his portrait (fig. 4 and 6). In the period immediately following he painted numerous portraits of Nicolay's older brother George (fig. 5, 7 and 9), a man who until his early death continually played a significant role in Danish musical life. By profession a businessman, he cultivated a musical career at the same time. In 1823 he wrote out a 200 item list of his compositions, of which many were played in Copenhagen in his lifetime. He died in 1825, at the age of 35 . In 1843 his Six Songs were published and in 1983 one of his two symphonies was published. 